\title{
Impact of living mulches on the physical properties of Planosol in monocropped maize cultivation
}

\author{
Kęstutis Romaneckas ${ }^{1}$, Aida Adamavičienè ${ }^{1}$, Egidijus Šarauskis ${ }^{2}$, Zita Kriaučiūnienè ${ }^{3}$, Marek Marks ${ }^{4}$ \\ and Kristina Vaitauskien $\dot{e}^{2}$
}

\author{
${ }^{1}$ Institute of Agroecosystems and Soil Science, Aleksandras Stulginskis University, Studentu 11, 53361 \\ ${ }^{2}$ Institute of Agricultural Engineering and Safety, Aleksandras Stulginskis University, Studentu 15, 53362; \\ Akademija, Kaunas reg., Lithuania \\ ${ }^{3}$ Experimental Station, Aleksandras Stulginskis University, Rapsu 7, 53363, Noreikiskes, Kaunas reg., Lithuania \\ ${ }^{4}$ Department of Agroecosystems, University of Warmia and Mazury in Olsztyn, Poland
}

Received January 10, 2017; accepted December 29, 2017

\begin{abstract}
The complex mutual interactions between soil properties and plants in high-biodiversity mono-cropping agro ecosystems have not been widely investigated. For this purpose, during 2009-2011, a stationary field experiment was conducted at the Experimental Station of the Aleksandras Stulginskis University to establish the effect of a multi-component agrocenose (maize, living mulch, weeds) on the physical properties of the soil. Spring oilseed rape, white mustard, spring barley, Italian ryegrass, black medic, Persian clover and red clover were sown as living mulch into maize inter-rows. The stability of $>1.0 \mathrm{~mm}$ aggregates increased between the beginning and end of the maize vegetative period in almost all of the crops containing living mulch. The greatest competition for moisture content between the inter-crops and maize was observed at the beginning of the vegetative period because of living mulches of long growing seasons using the most moisture. In many cases, the shear strength of the soil was significantly reduced by the living mulch in the middle of summer, when it covered the maize inter-rows. These findings show that the monocropping of maize with living mulch stabilises or improves the physical characteristics of the soil, highlighting its potential for sustainable maize growing.

Keywords: intercropping, soil moisture content and shear strength, soil aggregate stability, Zea mays L.
\end{abstract}

\section{INTRODUCTION}

In Europe and many other regions of the world, the most convenient method for controlling pest plants in agricultural systems is through the use of selective herbicides that exterminate the target species and create better conditions for other species (Blackshaw et al., 2006). However, although this achieves high yields, the wide use of chemicals leads to environmental pollution. The sowing of living mulch plants between the rows of a main crop might be an effective environmentally friendly weed control method. The use of living mulch or cover crops as organic mulches has positive effects on the physical properties of the soil, such as temperature, moisture content, bulk density, structure and strength (Adamczewska-Sowinska et al., 2009; Duda et al., 2003; Haruna and Nkongolo, 2015; Zhang et al., 2009). In the investigations of Qian et al. (2015), in the use of three living mulch treatments - white clover (Trifolium repens L.), crown vetch (Coronilla varia L.) and perennial ryegrass (Lolium perenne L.) benefits were seen in the development of soil micro-ecology and soil quality. Furthermore, when living mulch as cover crop is left over winter, it also effectively stops water erosion and increases the content of soil organic matter (de Baets et al., 2007; Gyssels et al., 2005). Appropriately chosen cover crop species not only facilitate soil fertility, but also affect the formation of root channels in the soil (Ball et al., 2005). This process is known as 'biological drilling' (Cresswell and Kirkegaard, 1995). However, several studies have shown that this can only be performed by large-diameter taproots of dicotyledonous plants (Materechera et al., 
1992; Merrill et al., 2002). For example, oilseed radish (Raphanus sativus L.) is characterised by a large taproot, and white mustard (Sinapis alba L.) has a strong taproot and many lateral roots that can reach a depth of $70 \mathrm{~cm}$. By contrast, annual ryegrass (Lolium multiforum Lam.), perennial ryegrass and rye (Secale cereale L.) are characterised by a system of small roots that covers a considerable soil area (Cresswell and Kirkegaard, 1995). According to De Baets et al. (2011), ryegrass and rye crops exhibit the greatest level of root branching in the upper soil layer, and so these plants are considered to have the highest potential for reducing soil erosion. Nedzinskienè and Bakšienè (2010) found that the dense roots of cock's-foot (Dactylis glomerata L.) provided a strong sward during the year of sowing and protected the soil from erosion, which contained $69.7 \%$ of mezzo-aggregates in the $0-10 \mathrm{~cm}$ layer and $75.7 \%$ of mezzo-aggregates in the $10-20 \mathrm{~cm}$ layer. This can be compared with $55.7 \%$ and $60.9 \%$, respectively, in a soil covered with red clover.

The complex mutual interactions between soil properties and plants in high-biodiversity mono-cropping agroecosystems (crops, living mulch plants and weeds) have not been widely investigated. Therefore, the aim of our study was to determine the level of competition between maize, interrow living mulch plants and weeds in such agroecosystems, and their effect on the physical properties of the soil.

\section{MATERIALS AND METHODS}

A stationary field experiment was conducted during 2009-2011, at the Experimental Station of the former Lithuanian University of Agriculture (now called Aleksandras Stulginskis University) (54 $\left.52^{\prime} \mathrm{N}, 23^{\circ} 49^{\prime} \mathrm{E}\right)$. The soil at the experimental site was a silty loam $(46 \%$ sand, $42 \%$ silt, $12 \%$ clay) Endohypogleyic-Eutric Planosol (Ple-gln-w) (IUSS Working Group WRB, 2014), with a texture of silty light loam on heavy loam. The soil in experiment was neutral, and had a moderate amount of main nutrients and humus. Further details of the soil chemical composition during our experiment can be found in Adamavičiene et al. (2012). The climate at the experimental site is subarctic, the average annual precipitation is 720 $\mathrm{mm}$ on the coast of the Baltic Sea and $490 \mathrm{~mm}$ in the eastern part of the country, with a mean annual precipitation rate of $625.5 \mathrm{~mm}$ over the last 59 years.

In our experiment, so as to examine the effects of interseeding different living mulches in maize inter-rows on the physical properties of the soil, the following treatments were used: no living mulch (control-reference treatment, hand weeding only) (CT); spring rape (Brassica napus L.) (SR); white mustard (Sinapis alba L.) (WM); spring barley (Hordeum vulgare L.) (SB); Italian ryegrass (Lolium multiflorum Lam.) (IR); black medic (Medicago lupulina L.) (BM); Persian clover (Trifolium resupinatum L.) (PC); red clover (Trifolium pratense L.) (RC). In each year of our experiment, the same species of living mulch plants were sowed into the inter-rows of a maize crop. The control plots were weeded out 3 times. Each experimental treatment had four replicates with fully randomised design. The size of experimental plot was $24 \mathrm{~m}^{2}(8 \times 3 \mathrm{~m})$. Pesticides were not applied. Before sowing, complex NPK fertiliser (16:16:16) was used at a rate of $300 \mathrm{~kg} \mathrm{ha}^{-1}$ and incorporated at a depth of 4-5 cm. Maize was sown using a pneumatic-mechanical drill (Köngskilde PRECI-SEM). Distance between rows was $50 \mathrm{~cm}$, between seeds $-16-17 \mathrm{~cm}$. After the emergence of maize, the inter-rows were shallowly harrowed and living mulch plants were inter-sown. The living mulch plants were cut and distributed on the soil surface 3 times at maize growth stages $\mathrm{BBCH} 15-16,31-32$ and 63-65. We used a hand-operated brush cutter 'Stihl' FS-550. At the operation time, the living mulch plants had reached a height of up to $15-20 \mathrm{~cm}$. The maize crop was also fertilised with nitrogen $\left(\mathrm{N}_{60}\right)$ at the stem elongation stage (BBCH 31-32). After maize harvest, experimental plots were ploughed by a reversible plough with semi-helical mouldboards to a depth of $20-22 \mathrm{~cm}$.

In our experiment, we used the maize cultivar 'Silvestre'. The maize sowing rate was 130-138 thousand seeds per ha (or 20-23 $\mathrm{kg} \mathrm{ha}^{-1}$ ) or about by 30-50 thousand seeds per ha denser than usual in Lithuania. Spring rape (cv. 'Sponsor'), white mustard (cv. 'Braco'), Italian ryegrass (cv. 'Avance'), black medic (cv. 'Arka'), Persian clover (cv. 'Gorby') and red clover (cv. 'Nemuniai') were sown at a seed rate of $10 \mathrm{~kg} \mathrm{ha}^{-1}$. Sowing rate of spring barley (cv. 'Simba') was $200 \mathrm{~kg} \mathrm{ha}^{-1}$.

Soil moisture content (gravimetric water content, mass wetness; Hillel, 1982) was measured every 15 days from maize emergence to harvest. We used an auger for soil sampling. Soil samples were taken in no less than 10 places of each plot at 0-10 and 10-20 cm depths. Soil moisture content (mass wetness) was established by the weighting method. Soil shear strength was measured with a shear vane tester ('GEONOR 72410') after sowing the living mulches and then every 15 days until harvest. Shear strength was measured at the beginning (in 2009) and end (in 2011) of the experiment in 5 places in each plot at 15 and $25 \mathrm{~cm}$ depths of the arable layer.

Soil aggregate stability (SAS) (water resistance) was measured by taking samples from 5 places in each experimental plot to form a composite sample. SAS was determined by the wet sieving method after sowing the living mulches and before maize harvest. The experimental data were statistically analysed using single-factor analysis of variance (ANOVA) and correlation methods.

\section{RESULTS AND DISCUSSION}

Agricultural crop development and yield are affected by the physical properties of the soil, which mainly depend on the amount of crop residues (Jordán et al., 2010; He et 
al., 2011). Numerous authors have found a positive impact of crop residues on the content of stable soil aggregates (Jordán et al., 2010; Karami et al., 2012; Unger and Jones, 1998). Similarly, in our experiment, in 2009, the total amount of stable soil aggregates had a tendency to increase $(p>0.05)$ during the vegetative period in plots containing maize crops grown with spring barley, Italian ryegrass and black medic living mulches (Table 1). However, plots containing spring rapeseed and black medic living mulches had a higher total structural stability at the end of the vegetative period. The content of water-stable aggregates from 0.25 to $1.0 \mathrm{~mm}$ size increased in the plots containing spring rapeseed, spring barley, Italian ryegrass and black medic living mulches, but was highest with spring rapeseed and

Table 1. Effects of living mulches on soil aggregate stability (SAS, \%) $(0-20 \mathrm{~cm})$ at the beginning $(\mathrm{BBCH} 05-07)$ and end $(\mathrm{BBCH}$ 85-87) of the maize (Zea mays L.) vegetative growth period

\begin{tabular}{|c|c|c|c|c|c|c|c|}
\hline \multirow{2}{*}{ Treatment } & \multirow{2}{*}{$\begin{array}{l}\text { Fractions } \\
\quad(\mathrm{mm})\end{array}$} & \multicolumn{2}{|c|}{2009} & \multicolumn{2}{|c|}{2010} & \multicolumn{2}{|c|}{2011} \\
\hline & & Beginning & End & Beginning & End & Beginning & End \\
\hline \multirow{3}{*}{ CT } & total & 46.2 & 43.2 & 54.3 & 40.7 & 41.3 & 39.4 \\
\hline & $0.25-1$ & 39.6 & 38.5 & 41.3 & 29.7 & 34.2 & 33.2 \\
\hline & $>1$ & 6.6 & 4.7 & 12.9 & 11.0 & 7.1 & 6.2 \\
\hline \multirow{3}{*}{ SR } & total & 64.0 & 49.1 & 55.3 & 45.1 & 44.4 & 38.7 \\
\hline & $0.25-1$ & 41.9 & 42.2 & 43.7 & 34.7 & 36.3 & 29.7 \\
\hline & $>1$ & $4.1^{* *}$ & $6.9^{* *}$ & 11.6 & 10.3 & 8.1 & 9.0 \\
\hline \multirow{3}{*}{ WM } & total & 43.1 & 41.1 & 56.5 & 39.4 & 48.8 & 38.2 \\
\hline & $0.25-1$ & 38.3 & 36.9 & 44.9 & $22.8^{*}$ & 42.6 & 27.9 \\
\hline & $>1$ & 4.8 & 4.2 & 11.5 & 9.4 & 6.2 & $10.3^{* *}$ \\
\hline \multirow{3}{*}{ SB } & total & 39.9 & 41.5 & 56.3 & 41.2 & 42.4 & 41.7 \\
\hline & $0.25-1$ & 34.8 & 36.8 & 45.1 & 29.9 & 35.9 & 33.9 \\
\hline & $>1$ & 5.1 & 4.7 & 11.2 & 11.3 & 6.5 & 7.8 \\
\hline \multirow{3}{*}{ IR } & total & 37.7 & 41.6 & 53.3 & 35.4 & 36.0 & 34.0 \\
\hline & $0.25-1$ & 33.9 & 35.9 & 44.8 & 29.2 & 29.6 & 26.9 \\
\hline & $>1$ & $3.8^{* *}$ & 5.6 & $8.4^{* *}$ & $6.1^{*}$ & 6.4 & 7.1 \\
\hline \multirow{3}{*}{$\mathrm{BM}$} & total & 42.6 & 43.8 & 54.2 & 43.1 & 44.9 & 43.8 \\
\hline & $0.25-1$ & 37.1 & 38.8 & 43.6 & 31.1 & 37.0 & 34.9 \\
\hline & $>1$ & 5.6 & 5.0 & 10.6 & 11.9 & 7.8 & 8.9 \\
\hline \multirow{3}{*}{$\mathrm{PC}$} & total & 43.4 & 42.4 & 57.1 & 40.6 & 45.0 & 37.4 \\
\hline & $0.25-1$ & 39.2 & 36.8 & 42.5 & 31.7 & 37.8 & 30.3 \\
\hline & $>1$ & $4.2^{*}$ & 5.6 & 14.5 & 8.9 & 7.2 & 7.1 \\
\hline \multirow{3}{*}{$\mathrm{RC}$} & total & 46.1 & 42.9 & 50.4 & 37.0 & 41.4 & 35.5 \\
\hline & $0.25-1$ & 38.8 & 37.6 & 43.1 & 27.1 & 35.6 & 27.9 \\
\hline & $>1$ & 7.3 & 5.2 & $7.3^{* *}$ & 9.8 & 5.7 & 7.6 \\
\hline
\end{tabular}

${ }^{1}$ Total, soil fractions $\geq 0.25 \mathrm{~mm}$. CT - no living mulch (control-reference treatment, hand weeding only), SR - spring rape, WM - white mustard, SB - spring barley, IR - Italian ryegrass, BM - black medic, PC - Persian clover, RC - red clover. *significant difference at the $95 \%$ probability level $(\mathrm{p} \leq 0.05>0.01)$; **significant difference at the $99 \%$ probability level $(\mathrm{p} \leq 0.01>0.001) ; \mathrm{p}>0.05$, no significant difference at the $95 \%$ probability level. 
black medic. The stability of soil aggregates $>1.0 \mathrm{~mm}$ size increased in plots containing spring rapeseed (significantly higher by $46.9 \%$ ), Italian ryegrass and Persian clover living mulches. Likewise, Sun et al. (1995) found that the green manure of Fabaceae plants had a greater influence on the content of organic matter and stable soil aggregates than other fertilisers.

In 2010, the living mulches did not have a significant effect on soil aggregate stability at the beginning of the maize vegetative period (Table 1). However, at the end of the vegetative period, the total structural soil stability had increased by $17.9 \%$ in plots containing spring rapeseed, barley and black medic living mulches, while all other living mulches reduced the total structural stability, albeit insignificantly. At the beginning of the vegetative period, significantly lower contents of stable structural aggregates $>1.0 \mathrm{~mm}$ size were observed in plots containing Italian ryegrass (by 34.9\%) and red clover (by 43.8\%) living mulches when compared with control plots without intercropping. At the end of the vegetative period, the content of $0.25-1.0 \mathrm{~mm}$ size soil aggregates had decreased in all plots, but was greater in plots containing spring barley, black medic and red clover living mulches. In plots containing mustard living mulch, the content of $0.25-1.0 \mathrm{~mm}$ size stable aggregates significantly decreased by $23.0 \%$, while the content of $>1.0 \mathrm{~mm}$ aggregates decreased by $44.3 \%$.

In 2011, there was no significant difference in the structural stability between plots with and without living mulches at the beginning of the maize vegetative period (Table 1). However, at the end of the vegetation period, living mulches increased the stability of $>1.0 \mathrm{~mm}$ size aggregates, although this difference was only significant with white mustard living mulch (by 64.8\%).

In summary, these findings suggest that the sowing of cover crops as living mulch into maize inter-rows has a positive impact on the stability of $>1.0 \mathrm{~mm}$ size soil aggregates during the third year of the experiment at the end of the growing season. The stability of all investigated soil aggregates during the vegetative period increased in plots with spring barley and Black medic living mulches compared with the control plots. According to the Alvarez et al. (2017) meta-analysis (67 experiments), similarly with our findings, cover crops significantly increased the stability of the soil on an average by $12 \%$.

The shear strength of the soil depends on the different soil properties: penetration resistance, bulk density, porosity, texture and humus content, as well as freeze-thaw processes (Kairyte, 2005). In 2009, soil shear strength in the upper layer of soil $(15 \mathrm{~cm}$ depth) did not vary significantly between experimental plots at the beginning of the maize vegetative period (Table 2). However, in mid-July (BBCH 53-55), when the living mulches covered the soil surface, soil shear strength was from 16.8 to $26.3 \%$ lower in plots containing living mulches when compared with the weeded control plots without intercropping, and by the end of July (BBCH 63-65), a 19.5\% decrease in shear strength was observed in the plots containing black medic living mulch. At the end of the growing season (BBCH 75-79), living mulches did not have any significant effect on shear strength in the upper arable layer.

Significantly lower shear strength was recorded in the lower layer of soil ( $25 \mathrm{~cm}$ depth) in the plots containing red and Persian clover (by 19\%) living mulches at the beginning (BBCH 13-15) of the maize vegetative period when compared with the control plots (Table 2). This could be affected by the water uptake of living mulches resulting in different soil water content. In mid-July (BBCH 53-55), a $17.0 \%$ decrease in shear strength (on average) was observed in plots containing spring rapeseed, white mustard, spring barely, and black medic living mulches when compared with control plots with no intercropping. At the end of July (BBCH 63-65), spring rapeseed and black medic living mulches reduced the soil shear strength. Nevertheless, at the end of the vegetative period, living mulches had no significant effect on the shear strength of the arable layer.

In 2011, the shear strength in the upper $(15 \mathrm{~cm})$ and lower $(25 \mathrm{~cm})$ arable layers was not significantly different between plots at the beginning (BBCH 10-17) of the maize vegetative growth period (Table 2). However, in the middle of summer (30 Jun-15 July, BBCH 32-56), plots with living mulch had significantly lower soil shear strength than did control plots without living mulch, in both arable layers: at the end of June (BBCH 32-33), plots with spring barley (by $13.3 \%$ and 15.3\%) and Italian ryegrass (by 14.7 and $15.5 \%$ ) living mulches had lower shear strength; while in mid-July (BBCH 53-56), all plots with intercropping had lower soil shear strength than did the weeded control plots. A significant decrease in soil shear strength was also observed in the lower arable layer (by $13.0 \%$ on average) in plots containing spring rapeseed, white mustard, Italian ryegrass and black medic living mulches. At the end of the maize vegetative growth period, a larger decrease in shear strength (by $22.8 \%$ on average) was observed in the lower arable layer in plots containing spring rapeseed, white mustard, Persian clover and red clover living mulches. At this time, the above-ground part of these annual cover crops had already been withered and their roots had started to decompose, which may have had a significant impact on the shear strength of the lower soil layer. Furthermore, the perennial plants (red clover) develop a strong root system at the end of the season, which may also have contributed to the decrease in this indicator.

Moderately strong correlations $\left(\mathrm{R}_{2009}=-0.711^{*} ; \mathrm{R}_{2011}=\right.$ $-0.727 *)$ were found between soil shear strength at a depth of $15 \mathrm{~cm}$ and the content of living mulch biomass. By contrast, at a depth of $25 \mathrm{~cm}$, the living mulches only affected soil shear strength in $2011\left(\mathrm{R}=-0.816^{*}\right)$. Liu et al. (2014) similarly detected negative linear correlations between the reduction in soil shear strength and aboveground biomass, root weight density and root length density. 
Table 2. Effects of living mulches on soil shear strength (kPa) in 2009 and 2011

\begin{tabular}{|c|c|c|c|c|c|c|c|c|c|}
\hline \multirow{2}{*}{$\begin{array}{c}\text { Sampling time } \\
\text { (maize BBCH } \\
\text { stages) }\end{array}$} & \multirow{2}{*}{$\begin{array}{c}\text { Sampling } \\
\text { depth } \\
(\mathrm{cm})\end{array}$} & \multicolumn{8}{|c|}{ Treatment } \\
\hline & & $\mathrm{CT}$ & SR & WM & SB & IR & $\mathrm{BM}$ & $\mathrm{PC}$ & $\mathrm{RC}$ \\
\hline \multicolumn{10}{|c|}{2009} \\
\hline \multirow{2}{*}{$09-10$} & 15 & 41.4 & 40.7 & 42.1 & 33.5 & 31.9 & 33.5 & 35.8 & 35.7 \\
\hline & 25 & 66.2 & 62.0 & $55.6^{*}$ & 59.6 & 57.5 & 60.9 & $54.1 *$ & 59.1 \\
\hline \multirow{2}{*}{$13-15$} & 15 & 53.9 & 52.4 & 59.7 & 43.1 & 45.9 & 54.5 & 51.4 & 48.9 \\
\hline & 25 & 78.5 & 72.3 & 67.1 & 71.7 & 73.9 & 72.4 & $63.2 *$ & $63.3^{*}$ \\
\hline \multirow{2}{*}{$30-32$} & 15 & 41.5 & 41.2 & 42.5 & 41.1 & 42.2 & 38.4 & 43.8 & 41.0 \\
\hline & 25 & 51.9 & 49.3 & 48.6 & 53.2 & 55.9 & 48.7 & 49.4 & 46.5 \\
\hline \multirow{2}{*}{$53-55$} & 15 & 66.8 & $51.3^{*}$ & 55.6 & $49.5^{*}$ & $49.2 *$ & $50.1^{*}$ & $54.0 *$ & 60.7 \\
\hline & 25 & 84.6 & $67.9 *$ & $74.4^{*}$ & $70.4^{*}$ & 73.0 & $68.0 *$ & 72.4 & 78.5 \\
\hline \multirow{2}{*}{$63-65$} & 15 & 53.9 & 50.4 & 46.2 & 48.9 & 50.3 & $45.1 *$ & 46.9 & 49.3 \\
\hline & 25 & 84.6 & $67.9^{*}$ & 74.4 & 70.4 & 73.0 & $68.0^{*}$ & 72.4 & 78.5 \\
\hline \multirow{2}{*}{$75-79$} & 15 & 55.4 & 54.7 & 60.9 & 57.9 & 59.7 & 55.9 & 57.2 & 55.8 \\
\hline & 25 & 63.4 & 60.1 & 66.9 & 64.7 & 69.7 & 61.2 & 65.5 & 63.2 \\
\hline \multicolumn{10}{|c|}{2011} \\
\hline \multirow{2}{*}{$10-11$} & 15 & 43.6 & 40.6 & 41.3 & 39.6 & 38.7 & 41.7 & 40.5 & 44.1 \\
\hline & 25 & 48.7 & 47.2 & 45.4 & 44.5 & 39.3 & 47.7 & 44.5 & 45.4 \\
\hline \multirow{2}{*}{$15-17$} & 15 & 60.6 & 55.5 & 56.7 & 58.9 & 55.1 & 56.9 & 58.6 & 55.8 \\
\hline & 25 & 63.0 & 56.0 & 59.2 & 62.4 & 59.9 & 65.6 & 62.3 & 60.7 \\
\hline \multirow{2}{*}{$32-33$} & 15 & 41.4 & 40.4 & 39.3 & $35.9 *$ & $35.3^{*}$ & 38.0 & 40.0 & 38.1 \\
\hline & 25 & 45.0 & 42.8 & 41.4 & $38.1^{*}$ & $38.0^{*}$ & 40.8 & 42.4 & 41.3 \\
\hline \multirow{2}{*}{$53-56$} & 15 & 60.3 & 52.6 & $48.9 *$ & $49.2 *$ & $49.6^{*}$ & 51.0 & 51.9 & 54.9 \\
\hline & 25 & 61.1 & $52.8^{*}$ & $53.4^{*}$ & 54.3 & $52.8^{*}$ & $53.5^{*}$ & 56.2 & 56.6 \\
\hline \multirow{2}{*}{$63-65$} & 15 & 37.7 & 36.3 & 39.7 & 39.7 & 37.2 & 38.2 & 38.6 & 39.4 \\
\hline & 25 & 42.6 & 39.6 & 40.7 & 42.3 & 40.9 & 40.4 & 41.9 & 43.5 \\
\hline \multirow{2}{*}{$75-79$} & 15 & 38.5 & 35.3 & 39.5 & 36.4 & 34.7 & 34.5 & 35.5 & 42.7 \\
\hline & 25 & 43.0 & 39.8 & 44.8 & 40.5 & 39.5 & 38.2 & 39.8 & 42.9 \\
\hline \multirow{2}{*}{$81-83$} & 15 & 37.8 & 42.0 & 41.1 & 35.2 & 34.4 & 37.5 & 40.9 & 41.2 \\
\hline & 25 & 42.1 & 44.9 & 44.8 & 38.8 & 35.7 & 40.3 & 45.2 & 37.6 \\
\hline \multirow{2}{*}{$85-87$} & 15 & 46.6 & $34.4^{*}$ & 39.9 & 45.9 & 40.2 & 38.1 & 39.6 & 37.6 \\
\hline & 25 & 55.4 & $38.5^{* *}$ & $44.9 *$ & 53.1 & 45.8 & 45.7 & $45.4^{*}$ & $42.3^{*}$ \\
\hline
\end{tabular}

Explanations as in Table 1.

In conclusion, these findings suggest that living mulches managed to cover the maize inter-rows by the middle of the maize growing period, resulting in a significant decrease in soil shear strength in many cases.

Some researchers have suggested that living mulches such as winter vetch (Corack et al., 1991), red clover (Ewing et al., 1991) or winter rye (Raimbault and Vyn,
1991) can deplete the water content of the soil, having an adverse effect on the growth and yield of the cultivated plants being grown alongside them (Decker et al., 1994). In our experiment, in 2009, we found that there was no significant variation in soil moisture content in the upper arable layer $(0-10 \mathrm{~cm})$ between plots, but it was by $4.6 \%$ higher on average in control plots without living mulches 
Table 3. Effects of living mulches and precipitation rate $(\mathrm{mm})$ on soil water content (\%) in 2009

\begin{tabular}{|c|c|c|c|c|c|c|c|c|c|c|}
\hline \multirow{2}{*}{$\begin{array}{c}\text { Sampling } \\
\text { time } \\
\text { (maize } \\
\text { BBCH } \\
\text { stages) }\end{array}$} & \multirow{2}{*}{$\begin{array}{l}\text { Sampling } \\
\text { depth } \\
\text { (cm) }\end{array}$} & \multicolumn{8}{|c|}{ Treatment } & \multirow{2}{*}{$\begin{array}{c}\text { Precipi- } \\
\text { tation } \\
\text { rate } \\
(\mathrm{mm})^{1}\end{array}$} \\
\hline & & $\mathrm{CT}$ & SR & WM & SB & IR & $\mathrm{BM}$ & $\mathrm{PC}$ & $\mathrm{RC}$ & \\
\hline \multirow{2}{*}{$09-10$} & $0-10$ & 17.9 & 16.8 & 16.9 & 17.2 & 16.0 & 17.2 & 16.7 & 15.8 & \multirow{2}{*}{7.3} \\
\hline & $10-20$ & 19.5 & 18.6 & 18.5 & 19.2 & 19.3 & 19.3 & 18.4 & 18.1 & \\
\hline \multirow{2}{*}{$13-15$} & $0-10$ & 13.6 & 12.2 & 13.7 & 13.1 & 11.9 & 13.2 & 10.4 & 12.7 & \multirow{2}{*}{7.8} \\
\hline & $10-20$ & 17.9 & 16.2 & 16.9 & 16.1 & 14.8 & 17.1 & $14.7^{*}$ & 15.8 & \\
\hline \multirow{2}{*}{$30-32$} & $0-10$ & 18.2 & 18.1 & 18.3 & 18.4 & 19.9 & 18.9 & 17.8 & 16.0 & \multirow{2}{*}{2.1} \\
\hline & $10-20$ & 19.7 & 18.4 & 19.1 & 19.4 & 16.7 & 19.5 & 18.5 & 18.3 & \\
\hline \multirow{2}{*}{$53-55$} & $0-10$ & 15.7 & 16.9 & 16.3 & 17.1 & 15.8 & $17.9^{*}$ & 17.1 & 15.4 & \multirow{2}{*}{1.8} \\
\hline & $10-20$ & 18.2 & 14.5 & 17.1 & 18.3 & 16.1 & 18.7 & 17.9 & $15.7^{*}$ & \\
\hline \multirow{2}{*}{$63-65$} & $0-10$ & 17.1 & 17.6 & 17.2 & 18.5 & 16.5 & 18.8 & 17.4 & 15.9 & \multirow{2}{*}{0.1} \\
\hline & $10-20$ & 18.7 & 18.5 & 18.2 & 19.2 & 17.2 & 19.7 & 19.0 & 17.7 & \\
\hline \multirow{2}{*}{$75-79$} & $0-10$ & 14.5 & 12.8 & 13.2 & 14.0 & 12.6 & 15.1 & 14.2 & $11.4 *$ & \multirow{2}{*}{4.3} \\
\hline & $10-20$ & 15.6 & 14.2 & 15.0 & 15.8 & 14.2 & 15.7 & 15.6 & 13.1 & \\
\hline \multirow{2}{*}{$81-83$} & $0-10$ & 19.7 & 20.0 & 19.5 & 20.2 & 18.9 & 20.5 & 19.8 & 19.1 & \multirow{2}{*}{40.6} \\
\hline & $10-20$ & 19.8 & 18.8 & 18.8 & 19.1 & 18.0 & 19.8 & 18.9 & 18.4 & \\
\hline \multirow{2}{*}{$85-87$} & $0-10$ & 18.2 & 18.0 & 17.6 & 18.4 & 17.9 & 18.8 & 17.8 & 17.0 & \multirow{2}{*}{0.2} \\
\hline & $10-20$ & 19.3 & 17.8 & 17.3 & 18.4 & $16.9^{*}$ & 18.7 & 18.5 & $16.9^{*}$ & \\
\hline
\end{tabular}

${ }^{1}$ Precipitation rate during the period between each sampling date. Other explanations as in Table 1.

(Table 3). A similar trend was also seen in the deeper (10$20 \mathrm{~cm}$ ) arable layer, where the soil moisture content was by $3.9 \%$ higher without intercropping, but not significantly different between plots. Observation of plots in which Italian ryegrass was sown in the maize inter-rows showed that in the middle of the summer (BBCH 53-79), Italian ryegrass began to grow faster, resulting in increased moisture use, particularly after cutting. Similarly, Liedgens et al. (2004) found that the soil water content in plots containing maize with Italian ryegrass living mulch was always lower at depths of 0.3 and $0.6 \mathrm{~m}$ than in plots without intercropping. We also found that the cultivation of ryegrass in maize inter-rows reduced the moisture content on average by $3.6 \%$ in the upper arable layer and by $10.7 \%$ in the lower arable layer during the growing season (Table 3), while red clover living mulch reduced the moisture content by $8.3 \%$ in the upper arable layer and by $9.7 \%$ in the lower arable layer on average during all vegetative growth periods, when compared with control plots without living mulch. The plots containing black medic as living mulch exhibited the highest moisture contents on the soil surface, with a $4.8 \%$ higher water content on average than did the control plots without intercropping. In earlier Rasse et al. (2000) investigations, black medic living mulch reduces moisture evaporation and increases moisture content on the soil surface as well.

In our experiment, Persian clover living mulch required more moisture at the beginning (maize $\mathrm{BBCH} 13-15$ ) of the vegetative period, with a $17.9 \%$ significant reduction in moisture content in the lower arable layer, when compared with the control treatment - although this effect was not seen in later maize development stages.

In 2010, we obtained similar results as in 2009 (Table 4). Significantly lower moisture content levels (by $14.3 \%$ ) were observed in the lower arable layer by the end of June (BBCH 30-32) in plots containing maize crop with Italian ryegrass cultivated in the inter-rows, and on the 21 st of July (BBCH 53-55), in plots containing red clover living mulches (by $21.8 \%$ ), when compared with control plots without living mulches. The black medic living mulch consumed the least amount of moisture during the growing season, with the upper layer moisture content being by $3.4 \%$ higher on average than observed in the control plots.

At the beginning of the maize vegetative period in 2011, the moisture content was by $4.6 \%$ in the upper layer and by $5.0 \%$ higher in the lower layer of control plots without intercropping (Table 5). During the second 10-day 
Table 4. Effects of living mulches and precipitation rate $(\mathrm{mm})$ on soil water content $(\%)$ in 2010

\begin{tabular}{|c|c|c|c|c|c|c|c|c|c|c|}
\hline \multirow{2}{*}{$\begin{array}{c}\text { Sampling } \\
\text { time } \\
\text { (maize } \\
\text { BBCH } \\
\text { stages) }\end{array}$} & \multirow{2}{*}{$\begin{array}{c}\text { Sampling } \\
\text { depth } \\
(\mathrm{cm})\end{array}$} & \multicolumn{8}{|c|}{ Treatment } & \multirow{2}{*}{$\begin{array}{c}\text { Precipi- } \\
\text { tation } \\
\text { rate } \\
(\mathrm{mm})\end{array}$} \\
\hline & & $\mathrm{CT}$ & SR & WM & SB & IR & $\mathrm{BM}$ & $\mathrm{PC}$ & $\mathrm{RC}$ & \\
\hline \multirow{2}{*}{$09-10$} & $0-10$ & 19.9 & 19.3 & 19.6 & 19.5 & 17.7 & 19.5 & 18.7 & 17.8 & \multirow{2}{*}{10.3} \\
\hline & $10-20$ & 19.9 & 21.0 & 20.1 & 20.5 & 18.7 & 20.9 & 20.3 & 19.4 & \\
\hline \multirow{2}{*}{$13-15$} & $0-10$ & 16.9 & 16.5 & 15.9 & 17.8 & 15.2 & 16.7 & 17.2 & 14.9 & \multirow{2}{*}{5.7} \\
\hline & $10-20$ & 19.9 & 20.2 & 19.7 & 20.1 & 18.4 & 20.0 & 19.5 & 18.6 & \\
\hline \multirow{2}{*}{$17-19$} & $0-10$ & 18.2 & 18.8 & 18.3 & 18.5 & 16.9 & 18.9 & 17.4 & 16.4 & \multirow[t]{2}{*}{12.0} \\
\hline & $10-20$ & 19.9 & 19.7 & 19.7 & 19.9 & 18.6 & 20.0 & 19.6 & 18.0 & \\
\hline \multirow{2}{*}{$30-32$} & $0-10$ & 16.9 & 15.7 & 15.8 & 16.6 & 14.8 & 17.7 & 17.4 & 14.5 & \multirow{2}{*}{0.0} \\
\hline & $10-20$ & 20.3 & 20.1 & 19.2 & 19.9 & $17.4^{*}$ & 19.4 & 18.0 & 18.6 & \\
\hline \multirow{2}{*}{$53-55$} & $0-10$ & 14.0 & 14.2 & 17.7 & 13.5 & 12.6 & 14.3 & 13.3 & 12.1 & \multirow{2}{*}{4.0} \\
\hline & $10-20$ & 17.4 & 16.8 & 16.7 & 16.3 & 14.9 & 16.2 & 16.4 & $13.6^{*}$ & \\
\hline \multirow{2}{*}{$61-63$} & $0-10$ & 17.9 & 18.6 & 18.1 & 18.2 & 16.9 & 19.1 & 18.1 & 17.2 & \multirow{2}{*}{5.5} \\
\hline & $10-20$ & 18.2 & 19.0 & 17.4 & 18.0 & 17.1 & 18.4 & 17.5 & 16.4 & \\
\hline \multirow{2}{*}{$77-79$} & $0-10$ & 20.6 & 20.5 & 19.5 & 20.5 & 19.7 & 21.1 & 21.0 & 19.7 & \multirow{2}{*}{36.0} \\
\hline & $10-20$ & 19.3 & 19.1 & 19.1 & 19.0 & 17.8 & 19.8 & 20.5 & 18.1 & \\
\hline \multirow{2}{*}{$83-87$} & $0-10$ & 17.6 & 18.8 & 18.3 & 18.0 & 16.6 & 18.9 & 21.6 & 16.9 & \multirow{2}{*}{1.2} \\
\hline & $10-20$ & 19.1 & 20.1 & 18.6 & 19.6 & 17.6 & 19.6 & 18.7 & 17.4 & \\
\hline
\end{tabular}

Explanations as in Table 1.

period in June (BBCH 15-17), there was only $0.9 \mathrm{~mm}$ of precipitation, resulting in the living mulches having a significant effect on moisture content. The moisture content in the upper arable layer decreased in plots containing maize crops with spring rapeseed (by 26.4\%), Italian ryegrass (by $24.8 \%$ ) and red clover (by $32.8 \%$ ) living mulches; and the living mulches also removed significantly more moisture (by $22.8 \%$ on average) from the lower arable layer in all plots except those sown with Italian ryegrass and black medic, when compared with plots without intercropping. The black medic living mulch did not reduce the arable layer moisture content throughout the entire maize vegetative period. There were statistically reliable negative correlations between living mulch dry mass and moisture content in the lower $(10-20 \mathrm{~cm})$ arable layer $(\mathrm{R}=-0.753)$. Similarly, Romaneckas et al. (2015) found significant correlations between soil moisture content before pre-sowing tillage in spring and the percentage of soil coverage by winter wheat (Triticum aestivum $\mathrm{L}$.) straw $(\mathrm{R}=0.413)$, and the volumes of mega-size $(>10 \mathrm{~mm})$ and macro-size $(0.25-10 \mathrm{~mm})$ soil structure (MES and MAS, respectively) in the upper $(0-15 \mathrm{~cm})$ arable layer $\left(\mathrm{R}=0.757^{* *}\right.$ and $-0.762^{* *}$, respectively); and Harasim et al. (2016) demonstrated that soil moisture depends on the mulching treatment used on the soil layer.
In summary, these findings suggest that living mulches with a long vegetative period use the largest amount of moisture, with Italian ryegrass and red clover living mulches having the highest moisture use in our experiment.

\section{CONCLUSIONS}

1. In the first two years of the experiment, the intercropping of living mulches in maize crop mainly had insignificant effect on the stability of soil structural aggregates. However, the positive impact of cover crops on the stability of $>1.0 \mathrm{~mm}$ aggregates became evident during the third experimental year, with the stability of these aggregates increasing in all plots containing living mulches except those sown with Persian clover. Plots that were sown with white mustard living mulch demonstrated significantly higher (by $64.8 \%$ ) stability of soil than did control plots without living mulches.

2. The coverage of living mulch residues lead to a significant reduction in soil shear strength in many cases. There were moderate negative correlations between the dry biomass of the living mulches and the shear strength at a depth of $15 \mathrm{~cm}$.

3. Italian ryegrass and red clover living mulches had the highest levels of moisture consumption. Black medic also has a long vegetative period, but used the least amount of 
Table 5. Effects of living mulches and precipitation rate ( $\mathrm{mm})$ on soil water content (\%) in 2011

\begin{tabular}{|c|c|c|c|c|c|c|c|c|c|c|}
\hline \multirow{2}{*}{$\begin{array}{c}\text { Sampling } \\
\text { time } \\
\text { (maize } \\
\text { BBCH } \\
\text { stages) }\end{array}$} & \multirow{2}{*}{$\begin{array}{c}\text { Sampling } \\
\text { depth } \\
(\mathrm{cm})\end{array}$} & \multicolumn{8}{|c|}{ Treatment } & \multirow{2}{*}{$\begin{array}{l}\text { Precipi- } \\
\text { tation } \\
\text { rate } \\
(\mathrm{mm})\end{array}$} \\
\hline & & $\mathrm{CT}$ & SR & WM & SB & IR & $\mathrm{BM}$ & $\mathrm{PC}$ & $\mathrm{RC}$ & \\
\hline \multirow{2}{*}{$10-11$} & $0-10$ & 16.1 & 15.8 & 15.6 & 15.9 & 14.7 & 15.8 & 15.2 & 14.8 & \multirow{2}{*}{9.2} \\
\hline & $10-20$ & 19.1 & 18.8 & 18.3 & 19.5 & 17.5 & 18.7 & 18.6 & 17.3 & \\
\hline \multirow{2}{*}{$15-17$} & $0-10$ & 12.5 & $9.2^{*}$ & 10.1 & 10.8 & $9.4^{*}$ & 9.6 & 9.6 & $8.4^{*}$ & \multirow{2}{*}{0.9} \\
\hline & $10-20$ & 15.4 & $12.3 *$ & $11.6^{*}$ & $11.6^{*}$ & 12.9 & 13.3 & $12.0 *$ & $11.9 *$ & \\
\hline \multirow{2}{*}{$32-33$} & $0-10$ & 14.3 & 13.0 & 13.5 & 13.7 & 13.8 & 14.2 & 13.1 & 12.8 & \multirow{2}{*}{34.0} \\
\hline & $10-20$ & 17.2 & $15.5^{*}$ & 15.9 & 16.2 & 16.6 & 16.0 & $15.3^{*}$ & $15.4^{*}$ & \\
\hline \multirow{2}{*}{$53-56$} & $0-10$ & 15.1 & 16.0 & 15.0 & 15.0 & 15.1 & 16.4 & 16.0 & 14.6 & \multirow{2}{*}{6.3} \\
\hline & $10-20$ & 17.8 & 17.7 & 17.0 & 16.9 & 16.2 & 17.6 & 17.7 & 16.4 & \\
\hline \multirow{2}{*}{$63-65$} & $0-10$ & 20.2 & 20.4 & 20.7 & 20.5 & 19.9 & 20.9 & 19.7 & 19.8 & \multirow{2}{*}{8.6} \\
\hline & $10-20$ & 20.3 & 21.0 & 20.5 & 21.2 & 19.8 & 21.2 & 19.6 & 19.8 & \\
\hline \multirow{2}{*}{$75-79$} & $0-10$ & 21.4 & 20.6 & 20.5 & 20.6 & 20.4 & 21.8 & 21.0 & 20.4 & \multirow{2}{*}{22.8} \\
\hline & $10-20$ & 21.3 & 21.5 & 20.3 & 20.5 & 19.3 & 21.3 & 21.6 & 20.0 & \\
\hline \multirow{2}{*}{$81-83$} & $0-10$ & 17.6 & 19.2 & 18.6 & 18.4 & 16.4 & 19.6 & 19.0 & 15.4 & \multirow{2}{*}{1.5} \\
\hline & $10-20$ & 18.9 & 19.2 & 18.6 & 18.8 & 16.7 & 19.3 & 18.6 & 16.3 & \\
\hline \multirow{2}{*}{$85-87$} & $0-10$ & 21.7 & 22.1 & 21.1 & 22.5 & 20.9 & 22.7 & 22.6 & 20.8 & \multirow{2}{*}{15.2} \\
\hline & $10-20$ & 21.5 & 23.2 & 21.4 & 22.1 & 19.6 & 21.9 & 20.7 & 20.2 & \\
\hline
\end{tabular}

Explanations as in Table 1.

moisture across all plots. 4 . The cultivation of maize crops with living mulch intercropping over a three-year period mainly improved the physical characteristics of the soil and prevented its degradation. Therefore, this may represent a suitable method for improving maize monocropping technologies under sustainable farming conditions.

Conflict of interest: The Authors declare no conflict of interest.

\section{REFERENCES}

Adamavičienė A., Romaneckas K., Pilipavičius V., Avižienytė D., Šarauskis E., and Sakalauskas A., 2012. Interaction of maize and living mulch: Soil chemical properties and bioactivity. J. Food, Agric Environ., 10(3-4), 1219-1223.

Adamczewska-Sowinska K., Kolota E., and Winiarska S., 2009. Living mulches in field cultivation of vegetables. Vegetable Crops Research Bulletin, 70, 19-29.

Alvarez R., Steinbach H.S., and De Paepea J.L., 2017. Cover crop effects on soils and subsequent crops in the pampas: A meta-analysis. Soil Till Res., 170, 53-65.

Ball B.C., Bingham I., Rees R.M., Watson C.A., and Litterick A., 2005. The role of crop rotations in determining soil structure and crop growth conditions. Can J. Soil Sci., 85, 557-577.
Blackshaw R.E., Moyer J.R., Doram R.C., and Boswell A.L., 2001. Yellow sweet clover, green manure, and its residues effectively suppress weeds during fallow. Weed Sci., 49(3), 406-413.

Corack S.J., Frye W.W., and Smith M.S., 1991. Legume much and nitrogen fertiliser effects on water and corn production. Soil Sci. Soc. Am. J., 55, 1395-1400.

Cresswell H.P., and Kirkegaard J.A., 1995. Subsoil amelioration by plat roots - the process and the evidence. Aust. J. Soil Res., 33, 221-239.

De Baets S., Poesen J., Knapen A., and Galindo P., 2007. Impact of root architecture, soil characteristics and flow shear stress on the erosion-reducing potential of roots during concentrated flow. Earth Surf. Proc. Land., 32, 1323-1345.

De Baets S., Poesen J., Meersmans J., and Serlet L., 2011. Cover crops and their erosion-reducing effects concentrated flow erosion. Catena, 85, 237-244.

Decker A.M., Clark A.J., Meisinger J.J., Mulford F.R., and McIntosh M.S., 1994. Legume cover crop contributions to no-tillage corn production systems. Agron J., 86, 126-135.

Duda G.P., Guerra J.G.M., Monteiro M.T., De-Polli H., and Teixeira M.G., 2003. Perennial herbaceous legumes as live soil mulches and their effects on $\mathrm{C}, \mathrm{N}$ and $\mathrm{P}$ of the microbial biomass. Sci. Agric. (Piracicaba, Braz.), 60, 139-147. 
Ewing R.P., Wagger G., and Denton H.P., 1991. Tillage and cover crop managements effects on soil water and corn yield. Soil Sci. Soc. Am. J., 55, 1081-1085.

Gyssels G., Pousen J., and Bouchet E.L.Y., 2005. Impact of plant roots and the resistance of soils to erosion by water. Prog Phys Geog., 29, 189-217.

Harasim E., Gawęda D., Wesołowski M., Kwiatkowski C., and Gocół M., 2016. Cover cropping influences physico-chemical soil properties under direct drilling soybean. Acta Agr. Scand B-S P., 66(1), 85-94.

Haruna S.I. and Nkongolo N.V., 2015. Effects of tillage, rotation and cover crop on the physical properties of a silt-loam soil. Int. Agrophys., 29, 137-145.

Hillel D., 1982. Introduction to Soil Physics. Academic Press, INC, Harcourt Brace Jovanovich, Publishers, San Diego, USA.

He J., Li H., Rasaily R.G., Wang Q., Cai G., Su Y., Qiao X., and Liu L., 2011. Soil properties and crop yields after 11 years of no tillage farming in wheat-maize cropping system in North China Plain. Soil Till Res., 113(1), 48-54.

Jordán A., Zavala L.M., and Gil J., 2010. Effects of mulching on soil physical properties and runoff under semi-arid conditions in southern Spain. Catena, 81(1), 77-85.

Kairytė A., 2005. Tillage intensity and straw incorporation effect on barley agrocenosis: summary of doctoral dissertation. Akademija press, Lithuania.

Karami A., Homaee M., Afzalinia S., Ruhipour H., and Basirat S., 2012. Organic resource management: impacts on soil aggregate stability and other soil physico-chemical properties. Agric. Ecosyst. Environ., 148, 22-28.

Liedgens M., Frossard E., and Richner P., 2004. Interactions of maize and Italian ryegrass in a living mulch system: (2) Nitrogen and water dynamics. Plant Soil, 259, 243-258.

Liu Y.J., Wang T.W., Cai C.F., Li Z.X., and Cheng D.B., 2014. Effects of vegetation on runoff generation, sediment yield and soil shear strength on road-side slopes under a simulation rainfall test in the three gorges reservoir area, China. Sci. Total Environ., 485, 93-102.
Materechera S.A., Alston A.M., Kirby J.M., and Dexter A.R., 1992. Influence of root diameter on penetration of seminal roots into a compacted subsoil. Plant Soil, 144, 297-303.

Merrill S.D., Tanaka D.L., and Hanson J.D., 2002. Root length growth of eight crop species in haplustoll soils. Soil Sci. Soc. Am. J., 66, 913-923.

Nedzinskienė T.M. and Bakšienė E., 2010. Yield of the grasses under sown in the winter rye crop and their influence on physical properties of sandy loam. Vagos, 89(42), 25-29.

Qian X., Gu J., Pan H.J., Zhang K.Y., Sun W., Wang X.J., and Gao H., 2015. Effects of living mulches on the soil nutrient contents, enzyme activities, and bacterial community diversities of apple orchard soils. Eur. J. Soil Biol., 70, 23-30.

Raimbault B.A. and Vyn T.J., 1991. Crop rotation and tillage effects on corn growth and soil structural stability. Agron J., 83, 979-985.

Rasse D.P., Smucker A.J.M., and Santos D., 2000. Alfalfa root and shoot mulching effects on soil hydraulic properties and aggregation. Soil Sci. Soc. Am. J., 64, 725-731.

Romaneckas K., Šarauskis E., Avižienytė D., Buragienė S., and Arney D., 2015. The main physical properties of planosol in maize (Zea mays L.) cultivation under different long-term reduced tillage practices in the Baltic region. J. Integr Agr., 14(7), 1309-1320.

Sun H., Larney F.J., and Bullock M.S., 1995. Soil amendments and water-stable aggregation of a resurfaced Dark Brown Chernozem. Can. J. Soil Sci., 75(3), 319-325.

Unger P.W. and Jones O.R., 1998. Long-term tillage and cropping systems affect bulk density and penetration resistance of soil cropped to dryland wheat and grain sorghum. Soil Till. Res., 45, 39-57.

WRB, 2014. World reference base for soil resources 2014. International soil classification system for naming soils and creating legends for soil maps. World Soil Resources Reports No. 106. FAO, Rome.

Zhang S., Lövdahl L., Grip H., Tong Y., Yang X., and Wang Q., 2009. Effects of mulching and catch cropping on soil temperature, soil moisture and wheat yield on the Loess Plateau of China. Soil Till. Res., 102(1), 78-86. 